\title{
Code-Switching in L2 Classrooms: A Useful Strategy to Reinforce Learning
}

\author{
Mustafa Altun ${ }^{1}$ \\ ${ }^{1}$ English Language Teaching Department, Tishk International University, Iraq \\ Email: mustafa.altun@tiu.edu.iq
}

DOI: $10.53103 /$ cjlls.v1i1.13

\begin{abstract}
Although teachers remain hesitant towards the use of L1 in L2 classes, L1 plays a pertinent role in foreign language learning to compensate for deficiencies for promoting language proficiency. For that reason, teachers show flexibility towards the use of code-switching in L2 learning situations to improve learning efficiency. Code-switching serves different functions in the language classroom; maintain the flow of conversation and facilitate communication, assist leaners in understanding linguistic forms, maintain learners' attention to lessons and encourage engagement in activities, create social classroom environment and establish interpersonal relationship between teachers and learners in the classroom. This paper aims to explore the potential benefits of code-switching in L2 classrooms.
\end{abstract}

Keywords: L1, L2, Language Learning, Code-Switching, Communication

\section{Introduction}

Code-switching, defined as "a phenomenon of switching from one language to another in the same discourse" (Numan \& Carter, 2001, p.275), has been occurring in bilingual and multilingual contexts to improve learning efficiency. More specifically, codeswitching refers to the alteration between two languages with the idea that switching between languages play a crucial role in the learning process (Moore, 2002). Codeswitching involves "going from one language to the other in mid speech when both speakers know the same two languages" (Cook, 2001, p.83). In other words, codeswitching refers to the shift to another language within the same conversation.

Language teachers remain hesitant towards the use of L1 in L2 classes because of the widespread assumption that the use of the target language in classroom settings can hinder development of language and communication. For instance, Willis (1981) states that "if the students start speaking in their own language without your permission... it generally means that something is wrong with the lesson" (p. xiv). Although language teachers try to minimize code-switching in the language classroom, the use of L1 in L2 learning situations is widely witnessed to promote metalinguistic awareness (Coste, 2000). 
A central task of teachers is to facilitate learners' access to knowledge in an easy way. It should be borne in mind that L1 is employed in foreign language learning to compensate for deficiencies for creating a relaxing learning environment, providing feedback to learners, reducing the anxiety of learners, improving self-confidence of learners, checking comprehension, giving instructions to learners, establishing classroom interaction, and removing learners' uncertainty. For that reason, code-switching can help learners with better comprehension and successful completion of tasks. It is also worth mentioning that the use of L1 in L2 classroom may be a need at a lower proficiency level. Moreover, L1 is helpful for the learners who are not familiar with daily uses of the target language. It should be emphasized that code-switching is a useful tool for language learners to reinforce L2 learning.

\section{Literature Review}

Code-switching is viewed as a linguistic behavior to accomplish social and pedagogical functions (Moodley, 2007). A growing body of literature support the use of code-switching owing to its contributions to the language learning process. Pennington (1995) demonstrates a move towards the use of code-switching in the language classroom to gain attention of learners and enhance interaction. Lin (1996) highlights that codeswitching can be used to clarify lexical items and make lesson materials more accessible to learners. Arthur (1996) advocates the use of code-switching for clarifying lesson content. It is noteworthy to mention that code-switching is helpful to reformulate content as it provides affective support to learners for better understanding. Cenoz (2007) asserts that metalinguistic awareness of bilinguals is more developed than that of monolinguals; for that reason, language teachers can use code-switching in the classroom to allow learners to make a comparison between L1 and L2.

The different functions of code-switching is divided into two approaches; the sociolinguistic approach and the grammatical approach (Hamers \& Blanc 2000). Sociolinguistic approach is related to "the topic of conversation, the participants, the setting, the affective aspect of the message" (Hamers \& Blanc 2000, p. 266), the grammatical approach is divided into three subcategories: 1) extra-sentential; codeswitching occurs as a question tag, 2) intersentential; code-switching occurs between sentences, and 3) intrasentential; code-switching occurs within the sentence (Hamers \& Blanc, 2000).

Many studies advocate using the target language in L2 classrooms as much as possible and consider switching to L1 as unnecessary (Macdonald, 2003; Cook, 2001). The underlying assumption is that L1 prevents exposure to L2; thus, impedes learning process. A commonly shared view is that teaching should be conducted in L2 because its exclusive use "develops the learners' own in-built language system" (Macaro, 2001, p. 531). 
However, excluding L1 from the language classroom may result in learner incomprehension. Carless (2007) advocates the use of L1 to encourage learners to take part in language learning activities and become competent L2 users and concludes that "any attempt to ban L1 use in the classroom would be detrimental to the amount of communication and learning taking place (p. 10). Harbord (1992) views the use of L1 as an important tool for language learning and states that "translation / transfer is a natural phenomenon and an inevitable part of second language acquisition ..., regardless of whether or not the teacher offers or 'permits' translation" (p. 351).

Speaking is a core component in language proficiency development (Mart, 2020). Code-switching in the field of foreign language teaching is employed in the discourse of teachers or learners. Hancock (1997) argues that learners need to practice in communicative exchanges in L2 classroom for the development of communicative language use. In classroom interaction code-switching is used to extend communicative competence to enable learners to accomplish their conversational goals. Reyes (2004, pp. 84-85) lists the conversational functions of code-switching as: (1) speech representation; code-switching is used to represent talk, (2) imitate quotation; code-switching is used to imitate the voice of particular character, (3) turn accommodation; code-switching occurs between learners' turns, (4) topic shift; code-switching is used in conversation when there is a change of topic, (5) situation switch; code-switching is employed to mark a switch between on and off topic conversation, (6) insistence; code-switching is used when a learner persists the same idea in both languages, (7) giving an emphasis; code-switching is used to emphasize a command, (8) clarification or persuasion; code-switching is employed to clarify an idea to enable learners to understand better, (9) persons specification; learners code-switch when they refer to another learner, (10) question shift; learners code-switch when they need to ask something, and (11) as a discourse maker; linguistic elements which are not added to the content of an utterance. An additional function by Mattsson and Burenhult $(1999$, p. 9) is repetition, where "the repetition in the first language (L1) can be either partial or full and is often expanded with further information, but more frequently code switching is used as a repetition of the previously uttered sentences". Carless's (2007) in a study interviewed secondary school teachers in Hong and found that code-switching is a source for expressing meaning, identity, and humour.

Code-switching serves different functions in the language classroom. Some learners benefit from code-switching and overcome their communication problems. Teachers code-switch to maintain the flow of conversation and facilitate communication and learning. Code-switching is a strategy teachers use to maintain communication in the language classroom. Code-switching has a scaffolding role in producing appropriate language in classroom discourse. Moreover, teachers show flexibility towards the use of code-switching to assist leaners in understanding linguistic forms. That is to say that codeswitching strategies have the potential to simplify the linguistic context and encourage 
proficiency in the second language. The major reason learners code-switch is that their level of proficiency in the target language is not sufficient to convey their messages; that being the case, they code-switch to clarify their messages to ensure that they are understood during a conversation. Eldridge (1996) makes it clear that learners use code-switching for "reinforcing, emphasizing or clarifying" the messages they need to convey in L2 (p. 306). Ferguson (2009, pp. 231-232) postulates three broad functions of code-switching: codeswitching for constructing and transmitting knowledge, code-switching for classroom management, and code-switching for interpersonal relations and humanizing the classroom climate. Code-switching constitutes the basis for comprehension for some learners with a low language level. The provision of target language equivalent clarifies meaning and exposes learners to an understanding of language itself. Knowledge construction is leaners' creation of new ideas and understandings to help them think critically. Code-switching enables teachers to transmit the new information to learners more effectively which leads to better learning outcomes (Tan \& Lou, 2017). The use of code-switching for classroom management is conducive to successful instruction because it is a useful tool for "arrangement of the physical environment of the classroom, establishment of the rules and procedures, as well as maintaining the learners' attention to lessons and encouraging engagement in activities" (Brophy, 2006, p. 17). Moreover, code-switching can be an effective inviting way for classroom participation and learner contributions. Employing code-switching in language learning is a viable strategy to create social classroom environment in which greater personal warmth and learner involvement is encouraged. It goes without saying that high-quality interpersonal relationship between teachers and learners brings about creativity and improved accomplishment.

Eldridge (1996) suggests the following motivations for leaners' code-switching in the classroom: equivalence; learners code-switch when they do not know the required lexical item in the target code, floor-holding; learners code-switch to prevent communication breakdowns through filling the stopgaps with the use of the native language, metalanguage; learners talk about the tasks they are performing, evaluate and make comments, reiteration; learners codeswitch in order to clarify or reinforce the transmitted message, group membership; code-switching serves a social function in which members adapt to each other, conflict control; learners use code-switching to create ambiguity when there is a potential conflict, alignment and disalignment; learners in a particular speech in the language classroom either sustain their role and align themselves to the conversation as it is or codeswitch and seek a different role.

\section{Conclusion}

Code-switching is a communicative resource used by teachers and learners to fulfill their social and educational objectives. The occurrence of code-switching in the 
language classroom not only exposes learners to comprehensible input but also encourages them to interact and engage in conversations. Code-switching can be used for drawing attention of learners to content information. Explanation of new subject matter by using L1 contributes to understanding of new materials. Another function of code-switching is its use for reinforcing and emphasizing the messages which learners fail to understand. Also, code-switching plays a crucial role in shaping learner behavior though enabling them to involve in classroom activities. The role of code-switching in establishing interpersonal relationship between teachers and learners is also worth mentioning.

\section{References}

Arthur, J. (1994). English in Botswana primary classrooms: Functions and constraints. In C. Rubagumya (ed.), Teaching and Researching Language in African Classrooms (pp 63-78). Clevedon; Multilingual Matters.

Brophy, J. E. (2006). History of research in classroom management. In C. Evertson, \& C. Weinstein (Eds.), Handbook of classroom management: Research, practice, and contemporary issues (pp. 17-43). Mahwah, NJ: Lawrence Erlbaum Associates, Inc.

Carless, D. (2007). Student use of the mother tongue in the task-based classroom. ELT Journal, 62(4), 331-338.

Cenoz, J. (2007). The acquisition of pragmatic competence and multilingualism in foreign language contexts. In E. Alco'n Soler and M. P. Safont Jorda` (eds.). Intercultural language use and language learning. Dordrecht: Springer.

Cook, V. (2001). Second language learning and language teaching. London: Edward Arnold

Coste, D. (2000). Immersion, enseignement bilingue et construction des connaissances. Le Français dans le Monde: Actualité de l'enseignement Bilingue. Numéro spécial coord. J. Duverger, Hachette-Edicef, 118-124.

Eldridge, J. (1996). Code-Switching in a Turkish secondary school. ELT Journal, 50 (4), 303-311.

Ferguson, G. (2009). What next: Towards an agenda for classroom code switching research. International Journal of Bilingual Education and Bilingualism, 12(2), 231-241.

Hamers, Josiane, F. \& Michael, H. A. (2000). Bilinguality and bilingualism. 2nd edn. Cambridge: Cambridge University Press.

Hancock, M. (1997). Behind classroom code-switching: Layering and language choice in L2 learner interaction. TESOL Quarterly, 31(2), 217-235.

Harbord, J. (1992). The use of the mother tongue in the classroom. ELT Journal, 46(4), $350-355$

Lin, A. (1996). Bilingualism or linguistic segregation? Symbolic domination, resistance and Code-Switching in Hong Kong schools. Linguistics and Education, 8, 9-84. 
Macaro, E. (2001). Analysing student teachers' codeswitching in foreign language classrooms: Theories and decision making. The Modern Language Journal, 85, iv, 531-548.

Macdonald, C. (1993). Using the target language. Cheltenham: Mary Glasgow Publications.

Mart, Ç.T. (2020). Integrating listening and speaking skills to promote speech production and language development. Mextesol Journal, 44 (2), 1-7.

Mattsson, A. F., \& Burenhult, N. (1999). Code-switching in second language teaching of French. Lund University, Dept. of Linguistics 1 Working Papers, 47, 59-72. Retrieved December 28th, 2015, from http://portal.research.lu.se/ws/files/6233889/624446.pdf

Moodley, V. (2007). Codeswitching in the Multilingual English First Language Classroom. International Journal of Bilingual Education and Bilingualism, 10(6), 707-722.

Moore, D. (2002). Code-switching and learning in the classroom. International Journal of Bilingual Education and Bilingualism, 5(5), 279-293.

Numan, D., \& Carter, D. (2001). Teaching English to speakers of other languages. Cambridge: Cambridge University Press.

Pennington, M. (1995). Pattern and variation in use of two languages in the Hong Kong secondary English class. RELC Journal, 80-105.

Reyes, I. (2004). Functions of code-switching in schoolchildren's conversation. Bilingual Research Journal, 28(1), 77-98.

Tan, N. S., \& Low, H. M. (2017). Socio-environmental factors impacting on teachers' attitudes towards code-switching in ESL classrooms in a rural district in Malaysia. Kajian Malaysia, 35(2), 105-125.

Willis, J. (1981). Teaching English through English. Harlow: Longman. 